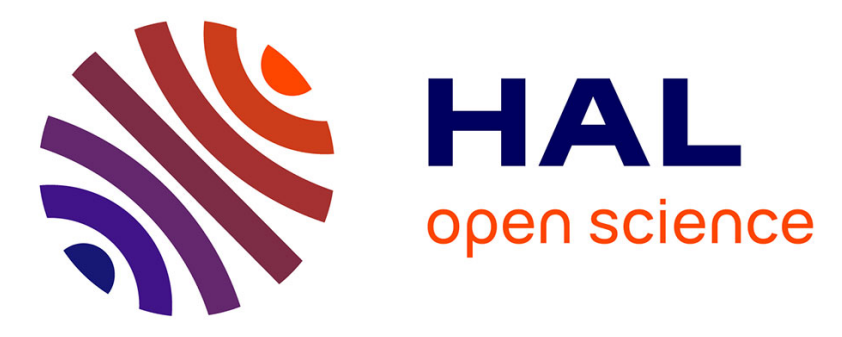

\title{
MRI measurement of liver fat content predicts the metabolic syndrome
}

Pierre-Henri Ducluzeau-Fieloux, Jérôme Boursier, Sandrine Bertrais, Séverine

Dubois, A Gauthier, Vincent Rohmer, Frédéric Gagnadoux, Georges

Lefthériotis, Paul Calès, Ramaroson Andriantsitohaina, et al.

\section{To cite this version:}

Pierre-Henri Ducluzeau-Fieloux, Jérôme Boursier, Sandrine Bertrais, Séverine Dubois, A Gauthier, et al. MRI measurement of liver fat content predicts the metabolic syndrome. Diabetes \& Metabolism, 2013, 39 (4), pp.314-321. 10.1016/j.diabet.2013.01.007 . hal-03328675

\section{HAL Id: hal-03328675 \\ https://univ-angers.hal.science/hal-03328675}

Submitted on 30 Aug 2021

HAL is a multi-disciplinary open access archive for the deposit and dissemination of scientific research documents, whether they are published or not. The documents may come from teaching and research institutions in France or abroad, or from public or private research centers.
L'archive ouverte pluridisciplinaire HAL, est destinée au dépôt et à la diffusion de documents scientifiques de niveau recherche, publiés ou non, émanant des établissements d'enseignement et de recherche français ou étrangers, des laboratoires publics ou privés. 


\title{
Original article
}

\section{MRI measurement of liver fat content predicts the metabolic syndrome}

\author{
P.-H. Ducluzeau ${ }^{\mathrm{a}, \mathrm{g}, *}$, J. Boursier ${ }^{\mathrm{b}, \mathrm{c}}$, S. Bertrais ${ }^{\text {b,c }}$, S. Dubois ${ }^{\mathrm{a}, \mathrm{g}}$, A. Gauthier ${ }^{\mathrm{a}}$, V. Rohmer ${ }^{\mathrm{a}, \mathrm{g}}$, \\ F. Gagnadoux ${ }^{\mathrm{d}, \mathrm{g}}$, G. Leftheriotis ${ }^{\mathrm{e}}$, P. Cales ${ }^{\mathrm{b}, \mathrm{c}}$, R. Andriantsitohaina ${ }^{\mathrm{g}}$, V. Roullier $^{\mathrm{f}}$, C. $^{\text {Aubé }}{ }^{\mathrm{f}}$ \\ ${ }^{a}$ Department of Endocrinology-Diabetology-Nutrition, LUNAM université, université d'Angers, CHU d'Angers, 49100 Angers, France \\ ${ }^{\mathrm{b}}$ Department of Hepatology, LUNAM université, université d'Angers, CHU d'Angers, 49100 Angers, France \\ ${ }^{\mathrm{c}}$ Laboratory HIFIH, UPRES 3859, LUNAM université, université d'Angers, CHU d'Angers, 49100 Angers, France \\ ${ }^{\mathrm{d}}$ Department of Pneumology, LUNAM université, université d'Angers, CHU d'Angers, 49100 Angers, France \\ ${ }^{\mathrm{e}}$ Department of Vascular Exploration, LUNAM université, université d'Angers, CHU d'Angers, 49100 Angers, France \\ ${ }^{\mathrm{f}}$ Department of Radiology, LUNAM université, université d'Angers, CHU d'Angers, 49100 Angers, France \\ g Inserm, U1063, “oxidative stress and metabolic diseases", LUNAM université, université d'Angers, CHU d'Angers, 49100 Angers, France
}

Received 27 September 2012; received in revised form 21 January 2013; accepted 30 January 2013

\begin{abstract}
Background and aims. - The prevalence of non-alcoholic fatty liver disease among cardiometabolic patients is not completely known because liver biopsy cannot be routinely performed. However, as magnetic resonance imaging (MRI) allows accurate and safe measurement of the hepatic fat fraction (HFF), the aim of this study was to quantify liver fat content in a dysmetabolic adult population.

Methods. - A total of 156 adults were included in this cross-sectional study. Liver and visceral fat were assessed by MRI in these subjects, who presented with zero to five metabolic components of the metabolic syndrome (MetS). Arterial stiffness was recorded by ultrasonography, and the maximum Youden index was used to set the optimal HFF cutoff value predictive of the presence of the MetS.

Results. - Overall, $72 \%$ of participants displayed three or more MetS components. HFF ranged from $0.3 \%$ to $52 \%$ (mean $13.4 \%$ ). Age- and gender-adjusted HFF was positively correlated with BMI $(r=0.44)$, blood pressure $(r=0.19)$, triglyceridaemia $(r=0.22)$ and glycaemia $(r=0.31)$. MRI-measured visceral adipose tissue did not influence the relationship of steatosis with glycaemia, HOMA-IR and carotid stiffness, but there was a dose-response relationship between the number of MetS components and mean HFF. The optimal HFF for predicting the MetS was found to be $5.2 \%$ according to the maximum Youden index point.

Conclusion. - This study highlighted the impact of liver steatosis on cardiometabolic abnormalities with an optimal cutoff value of $5.2 \%$ for defining increased metabolic risk.
\end{abstract}

Crown Copyright @ 2013 Published by Elsevier Masson SAS. All rights reserved.

Keywords: Liver steatosis; Magnetic resonance imaging; The metabolic syndrome; Vascular stiffness

\section{Résumé}

Le degré de stéatose hépatique mesuré par IRM est un facteur prédictif de la présence d'un syndrome métabolique.

Contexte et objectifs. - La prévalence de stéatose hépatique non alcoolique chez les patients présentant des critères du syndrome métabolique est mal connue, principalement du fait que la biopsie du foie ne peut pas être faite systématiquement. L'imagerie par résonance magnétique (IRM) permet une mesure précise et sûre du fraction lipidique hépatique (HFF). Le but de cette étude était de quantifier le contenu lipidique du foie dans une population adulte dysmétabolique.

Méthodes. - Cent cinquante-six adultes ont été inclus dans cette étude transversale. Le degré de stéatose et la graisse viscérale ont été évalués par IRM. Les sujets ont été classés selon leur nombre de critère du syndrome métabolique (MetS), de zéro à cinq composantes. La rigidité artérielle a été enregistrée par l'échographie. L'indice maximal de Youden a été utilisé pour établir une valeur optimale de stéatose prédicive de la présence d'un MetS.

Résultats. - Soixante-douze pour cent des participants présentaient un MetS (soit plus de deux critères). La HFF variait de 0,3 à $52 \%$ (moyenne $13,4 \%)$. Après ajustement sur l'âge et le sexe, la HFF est positivement corrélée à l'IMC $(r=0,44)$, la pression artérielle $(r=0,19)$, la triglycéridé

Abbreviations: HFF, hepatic fat fraction; MRI, magnetic resonance imaging; MRS, magnetic resonance spectroscopy; MetS, metabolic syndrome; NAFLD, non-alcoholic fatty liver disease; PWV, Pulse wave velocity; T2D, type 2 diabetes.

* Corresponding author. Department of nutrition, CHU d'Angers, 4, rue Larrey, 49033 Angers, France. Tel.: +33 241354497 ; fax: +33 241355900.

E-mail address: phducluzeau @ chu-angers.fr (P.-H. Ducluzeau). 
$(r=0,22)$, et la glycémie $(r=0,31)$. La quantité de tissu adipeux viscéral, mesurée par IRM, n'a pas d'influence sur la relation de la stéatose avec la glycémie, le HOMA-IR et la rigidité carotidienne. Le degré de stéatose hépatique optimal qui prédit le mieux la présence d'un MetS a été établi à $5,2 \%$.

Conclusion. - Cette étude a mis en évidence l'impact de la stéatose hépatique sur les anomalies cardio-métaboliques caractérisant le SM avec une valeur seuil optimale de $5,2 \%$ pour la définition d'un risque métabolique accru.

Crown Copyright @ 2013 Publié par Elsevier Masson SAS. Tous droits réservés

Mots clés : Stéatose hépatique ; Imagerie par résonance magnétique ; Syndrome métabolique ; Rigidité vasculaire

\section{Introduction}

The prevalences of both type 2 diabetes (T2D) and cardiovascular disease are increasing worldwide, and more effort is needed to understand the pathophysiology of these conditions. Insulin resistance is the common physiological basis of both liver steatosis and the metabolic syndrome (MetS), and is present long before the diagnosis of diabetes [1,2]. Adipose tissue is commonly associated with insulin resistance but, more recently, studies have shown that the accumulation of fat in the visceral cavity and particularly in the liver, is more closely related to insulin resistance syndrome than overall adiposity [3-5]. It is now widely accepted that fatty liver is part of the MetS and that non-alcoholic fatty liver disease (NAFLD) shares the same molecular characteristics as insulin resistance in hepatocytes [6-8]. The prevalence of NAFLD has increased to greater than $70 \%$ of subjects who have either the MetS or T2D, but it is important to note that the degree of steatosis can vary over time, with around 20 to $30 \%$ of patients studied showing a progression to steatohepatitis or fibrosis [9]. Evidence has also now accumulated that fatty liver measured by ultrasonography or estimated by blood tests can predict the risk of T2D and the MetS [10-14].

However, the impact of NAFLD on the progression of metabolic diseases has yet to be fully elucidated mainly because a standard and safe way to measure the degree of steatosis is still to be found. Liver biopsy is an invasive procedure that is not appropriate for either the evaluation or follow-up of liver steatosis in dysmetabolic patients. Also, its value is hampered by sampling bias, and it allows only semi-quantitative scoring of liver steatosis. For this reason, an accessible as well as noninvasive way of quantifying liver fat content would be useful for large clinical studies [15]. In this context, the reference radiological method for measurement of triglyceride (TG) accumulation in liver tissue is proton magnetic resonance spectroscopy $\left({ }^{1} \mathrm{H}-\right.$ MRS) [16]. The technique, however, requires specific software and stringent conditions to ensure that sequence acquisitions are reliable. Over the last couple of years, it has been demonstrated that magnetic resonance imaging (MRI) using multi-echo gradient sequences is very similar to ${ }^{1} \mathrm{H}-\mathrm{MRS}$ for quantifying liver fat content. Nevertheless, relevant clinical studies using MRI in a large number of subjects are still scarce [15-21].

In the present cross-sectional study, liver fat content was quantified using a validated MRI protocol in a cohort of French adults with various degrees of metabolic abnormalities. The purpose of the study was to clarify the relationship of the hepatic fat fraction (HFF) with each component of the MetS as well as with each patient's arterial stiffness.

\section{Patients and methods}

\subsection{Study population}

Altogether, 156 adult French subjects aged 30 to 75 years, initially referred to the department of nutrition for metabolic explorations, were selected for the study. These patients were also part of the NUMEVOX cohort and had all undergone MRI. The objective of the NUMEVOX cohort (Clinical trials number NCT00997165) was to describe the impact of fat distribution on vascular and metabolic evolution, and patients were recruited because the presence of the MetS was a criterion. Patients were classified into groups according to the presence or absence of the MetS (MetS+ or MetS-) or of type 2 diabetes (T2D). Presence of the MetS was defined according to Caucasian International Diabetes Federation (IDF) 2005 criteria [22]. Informed consent was obtained from each patient, and the study protocol had the approval of the local institution's human research committee. Exclusion criteria were a body mass index (BMI) greater than $40 \mathrm{~kg} / \mathrm{m}^{2}, \mathrm{HbA}_{1 \mathrm{c}}$ concentration greater than $9 \%$, insulin-treated diabetes, severe arterial hypertension $(>180 / 120 \mathrm{mmHg}$ ), severe hypertriglyceridaemia $(\mathrm{TG}>10 \mathrm{~g} / \mathrm{L}$ ), severe renal failure (creatinine clearance $<30 \mathrm{~mL} / \mathrm{min}$ ), viral or alcoholic hepatitis, and any contraindications for MRI.

\subsection{Clinical and biological measurements}

During hospitalization, weight, height and waist circumference were recorded as well as the 15-min brachial blood pressure, using an automatic blood pressure cuff. The waistto-hip ratio (WHR) and BMI were calculated. Blood samples were obtained after a 10-h fast and before any medications had been taken. All biochemical measurements were centralized. Leptin levels were measured using an enzyme-linked immunosorbent assay (ELISA, EMD Millipore, Billerica, MA, USA). Adiponectin was measured using an ELISA kit with intra- and inter-assay coefficients of variation of $7.25 \%$ and $6.32 \%$, respectively (EMD Millipore). Insulin resistance was determined by homoeostasis model assessment for insulin resistance (HOMA-IR; fasting serum insulin in $\mu \mathrm{U} / \mathrm{mL} \times$ glucose level in $\mathrm{mmol} / \mathrm{L}$ divided by 22.5 ).

\subsection{MRI assessment}

An abdominal MRI was performed on all 156 patients using a 1.5-T MR system (General Electric Medical Systems, Milwaukee, IL, USA) with a phased-array surface coil. Areas of 
visceral adipose tissue (VAT) and subcutaneous adipose tissue (SAT) were calculated on T1-weighted sequences using validated software [23]. HFF was quantified with a multiecho gradient-echo (MFGRE) sequence using a previously validated method $[24,25]$. HFF calculation was based on the signal intensities measured in two regions of interest in the anterior and posterior right lobe of the liver away from liver vessels.

\subsection{Vascular measurements}

Each patient also underwent supra-aortic trunk Doppler ultrasound with measurement of intima-media thickness (IMT) according to recommendations. Arterial stiffness was quantified by measuring the speed of the carotid pulse wave using an echo-tracking system coupled with ultrasound equipment (eTRACKING, Hitachi Aloka Medical Ltd, Tokyo, Japan) that allowed, after B-mode scanning, the simultaneous measurement of diameter variations and local pulse wave velocity (PWV) in the common carotid artery. A validated algorithm was used to calculate the local carotid PWV, which is directly proportional to carotid wall stiffness [26,27]. PWV was expressed as meters per second $(\mathrm{m} / \mathrm{s})$. The aortic PWV was measured using the same device by sequentially recording electrocardiogram-gated right carotid and femoral artery waveforms.

\subsection{Statistical analysis}

Statistical analysis was performed using standard procedures found in SAS software, version 9.2 (SAS Institute Inc., Cary, NC, USA). All variables with a skewed distribution were logarithmically transformed, and presented as geometric means together with $95 \%$ confidence intervals (CI). Categorical variables were compared using chi-square tests, and analysis of variance (ANOVA) was used for quantitative variables; when the global Fisher's test was significant, the Bonferroni method was applied to perform paired comparisons for multiple comparisons. HFF in relation to each parameter was expressed as gender- and age-adjusted Spearman's correlation coefficients. In addition, four different multivariate regression models were constructed to assess the association of hepatic fat content with the relevant metabolic and vascular parameters after controlling for age, gender and any additional potential confounding factors, including BMI and/or VAT and fasting insulin levels. Also evaluated was the performance of hepatic fat content to identify patients who had at least three characteristic abnormalities of the MetS. The cutoff point was fixed at the maximum value of the Youden index (sensitivity + specificity -1), and the diagnostic performance at this fixed cutoff level was measured in terms of diagnostic accuracy, including proportion of true positives and true negatives, sensitivity (Se), specificity (Sp), positive predictive value (PPV) and negative predictive value (NPV).

For all analyses, a $P$ value $<0.05$ was considered significant, and all tests were two-sided.

\section{Results}

\subsection{Characteristics of the study population}

A total of 156 subjects who had available HFF assessed by MRI scans were included in the present study. All were slightly younger than the 179 other participants in the NUMEVOX cohort $(52.9 \pm 9.8$ years vs $55.7 \pm 9.4$ years, respectively; $P<0.0067)$ and less frequently diabetic $(23.1 \%$ vs $34.6 \%$, respectively; $P<0.020$; data not shown). The study participants were divided in three groups: 68 had the MetS without diabetes (the "MetS+" group); 36 had T2D (the "T2D" group) treated only with metformin $(n=25)$ or no treatment $(n=11)$; and 52 had neither the MetS nor T2D (the "MetS-" group). The characteristics of all subjects according to group are shown in Table 1. The three groups were comparable in terms of gender and smoking status. As expected, the MetS+ patients had, on average, higher hepatic fat content as measured by MRI than the MetS- participants ( $15.0 \%$ vs $9.4 \%$, respectively), and T2D patients displayed the same mean level of steatosis as the MetS+ subjects. Also, the percentage of VAT was significantly larger in T2D patients than in MetS+ patients, while glycaemia showed significant increases across all three groups. Both MetS+ and T2D groups showed similar levels of insulin resistance based on HOMA-IR. Leptin levels were significantly higher only among the MetS+ participants, thereby supporting the observation that T2D patients have less subcutaneous fat than those who are MetS+. Systolic blood pressure, aortic PWV, and carotid IMT and PWV were lower among the MetS- group compared with the T2D and MetS+ patients, with no differences between the latter two groups.

\subsection{Correlation between hepatic fat fraction and anthropometric, metabolic, vascular and liver parameters}

Table 2 shows the associations between HFF and clinical and laboratory criteria of the MetS after adjusting for age and gender. There was a significant correlation between HFF and each of the following MetS criteria: waist circumference $(r=0.37)$; WHR $(r=0.27)$; systolic arterial blood pressure $(r=0.19)$; TG $(r=0.22)$; and glycaemia $(r=0.31)$. The strongest HFF relationships were found with BMI $(r=0.44)$ and the MRI-based VAT quantification $(r=0.39)$, whereas abdominal SAT was related to a lesser extent to HFF. Although both leptin and adiponectin were correlated with HFF in our subjects, there was better correlation with leptin $(r=0.28)$ than with adiponectin $(r=-0.17)$. The HOMA-IR index was strongly and positively associated with HFF for the whole of the study population $(r=0.44)$, with no differences across the three groups. Of the liver-related biological parameters, serum alanine aminotransferase (ALT) displayed the strongest relationship with HFF $(r=0.42)$, while gamma-glutamyl transferase (GGT) and ferritin levels were also related to HFF. In addition, a positive relationship was found between HFF and low-grade inflammation as assessed by Creactive protein (CRP) levels. HFF was also positively related to vascular stiffness (with aortic vessels more so than the carotids).

Table 3 shows the relationships between HFF and the relevant metabolic and vascular components after taking into account 
Table 1

Characteristics of the study participants according to their metabolic syndrome (MetS) and diabetes status.

\begin{tabular}{|c|c|c|c|c|c|c|}
\hline & $n$ & $\begin{array}{l}\text { MetS- } \\
(n=52)\end{array}$ & $\begin{array}{l}\text { MetS+ } \\
(n=68)\end{array}$ & $\begin{array}{l}\text { Type } 2 \text { diabetics } \\
(n=36)\end{array}$ & Global $P$ & Paired comparisons ${ }^{\mathrm{d}}$ \\
\hline Men, $n(\%)$ & 156 & $37(71.1)$ & $46(67.6)$ & $29(80.6)$ & 0.38 & - \\
\hline Smoker, $n(\%)$ & 156 & $11(21.2)$ & $14(20.6)$ & $2(5.6)$ & 0.10 & - \\
\hline Weight (kg) & 156 & $81.4 \pm 12.9$ & $93.6 \pm 15.0$ & $87.9 \pm 12.9$ & $<0.0001$ & a \\
\hline Height (m) & 156 & $1.69 \pm 0.09$ & $1.69 \pm 0.09$ & $1.69 \pm 0.10$ & 0.96 & - \\
\hline $\mathrm{BMI}\left(\mathrm{kg} / \mathrm{m}^{2}\right)$ & 156 & $28.5 \pm 4.8$ & $33.0 \pm 5.4$ & $31.0 \pm 4.2$ & $<0.0001$ & a \\
\hline WHR & 156 & $0.94 \pm 0.06$ & $0.98 \pm 0.07$ & $0.99 \pm 0.06$ & 0.0015 & $\mathrm{a}, \mathrm{b}$ \\
\hline Hepatic fat fraction (\%) & 156 & $9.4 \pm 10.3$ & $15.0 \pm 13.4$ & $16.8 \pm 14.0$ & 0.0129 & $\mathrm{a}, \mathrm{b}$ \\
\hline VAT $\left(\mathrm{cm}^{2}\right)$ & 156 & $132.5 \pm 72.4$ & $204.8 \pm 88.7$ & $217.7 \pm 87.5$ & $<0.0001$ & $\mathrm{a}, \mathrm{b}$ \\
\hline SAT $\left(\mathrm{cm}^{2}\right)$ & 156 & $203.1 \pm 87.4$ & $267.1 \pm 126$ & $224.6 \pm 143.6$ & 0.0145 & a \\
\hline VAT $(\%)$ & 156 & $38.5 \pm 16.7$ & $44.2 \pm 15.8$ & $49.5 \pm 16.6$ & 0.0086 & $\mathrm{~b}, \mathrm{c}$ \\
\hline Systolic BP (mmHg) & 156 & $121.4 \pm 12.6$ & $131.2 \pm 12.8$ & $130.0 \pm 14.8$ & 0.0003 & $a, b$ \\
\hline Glucose $(\mathrm{g} / \mathrm{L})$ & 156 & $0.95 \pm 0.09$ & $1.08 \pm 0.13$ & $1.32 \pm 0.23$ & $<0.0001$ & $\mathrm{a}, \mathrm{b}, \mathrm{c}$ \\
\hline Insulin $(\mathrm{mU} / \mathrm{L})^{\mathrm{e}}$ & 150 & $\begin{array}{l}10.2 \\
(8.7-11.9)\end{array}$ & $\begin{array}{l}17.2 \\
(15.0-19.6)\end{array}$ & $\begin{array}{l}15.3 \\
(12.7-18.5)\end{array}$ & $<0.0001$ & $\mathrm{a}, \mathrm{b}$ \\
\hline HOMA-IR & 150 & $\begin{array}{l}2.33 \\
(1.97-2.70)\end{array}$ & $\begin{array}{l}4.52 \\
(3.91-5.22)\end{array}$ & $\begin{array}{l}4.87 \\
(3.98-5.99)\end{array}$ & $<0.0001$ & $\mathrm{a}, \mathrm{b}$ \\
\hline Total cholesterol (g/L) & 156 & $2.14 \pm 0.46$ & $2.03 \pm 0.47$ & $1.92 \pm 0.38$ & 0.068 & - \\
\hline HDL cholesterol (g/L) & 156 & $0.61 \pm 0.15$ & $0.53 \pm 0.17$ & $0.55 \pm 0.17$ & 0.05 & - \\
\hline LDL cholesterol $(\mathrm{g} / \mathrm{L})$ & 156 & $1.30 \pm 0.38$ & $1.14 \pm 0.36$ & $1.07 \pm 0.29$ & $<0.0001$ & $\mathrm{a}, \mathrm{b}, \mathrm{c}$ \\
\hline Triglycerides $(\mathrm{g} / \mathrm{L})^{\mathrm{e}}$ & 156 & $\begin{array}{l}1.11 \\
(0.97-1.28)\end{array}$ & $\begin{array}{l}1.69 \\
(1.50-1.90)\end{array}$ & $\begin{array}{l}1.35 \\
(1.15-1.60)\end{array}$ & $<0.0001$ & a \\
\hline Leptin $(\mu \mathrm{g} / \mathrm{L})^{\mathrm{e}}$ & 146 & $\begin{array}{l}10.7 \\
(8.4-13.6)\end{array}$ & $\begin{array}{l}16.9 \\
(13.7-20.8)\end{array}$ & $\begin{array}{l}12.0 \\
(9.1-15.9)\end{array}$ & $<0.0001$ & a \\
\hline Adiponectin (mg/L) & 145 & $7.75 \pm 3.55$ & $7.30 \pm 3.28$ & $7.10 \pm 3.73$ & 0.67 & - \\
\hline
\end{tabular}

BMI: body mass index; WHR: waist-to-hip ratio; VAT: visceral adipose tissue; SAT: subcutaneous adipose tissue; BP: blood pressure; HbA $1 \mathrm{c}$ : glycosylated haemoglobin; HOMA-IR: homoeostasis model assessment for insulin resistance; HDL/LDL: high-density/low-density lipoprotein; IMT: intima-media thickness; PWV: pulse wave velocity.

${ }^{a} P<0.05$ for difference between MetS- and MetS+.

b $P<0.05$ for difference between MetS- and diabetics.

${ }^{c} P<0.05$ for difference between MetS+ and diabetics.

d By Bonferroni $t$ test.

e Skewed distribution of values: statistical tests were carried out on logarithmically transformed values; values are expressed as geometric means (95\% confidence interval).

other potential confounders, especially overall adiposity and its visceral distribution. In addition to age and gender, the multivariate regression analysis also included BMI, VAT and insulin levels (Table 4). Fasting serum glycaemia remained strongly and positively associated with HFF after adjusting for BMI and VAT $(P=0.003)$ and after considering insulin levels $(P=0.008)$. Moreover, the same results for HFF in relation to $\mathrm{HbA}_{1 \mathrm{c}}$ were found even after excluding T2D patients from the analysis (data not shown). The HFF-CRP relationship remained significant after adjusting for BMI and VAT, but was no longer significant after further adjustment for insulin levels and so was consistent with the well-known role of insulin resistance in low-grade inflammation. The HFF-to-systolic blood pressure relationship disappeared after adjusting for VAT, but not after adjusting for
BMI, while the relationship between aortic stiffness and HFF was lost after entering either BMI or VAT into the model. In contrast, the carotid stiffness and HFF relationship remained significant after adjusting for adiposity parameters, but disappeared only when insulin levels were included.

\subsection{Hepatic fat fraction, number of metabolic syndrome (MetS) components and cutoff value for MetS diagnosis}

Fig. 1 shows the degree of steatosis in participants grouped according to the number of MetS components they had (those with either zero or one component were pooled). HFF increased gradually with the number of MetS components $(P<0.0012$ for a linear trend). Among patients with fewer than two MetS 
Table 2

Gender- and age-adjusted Spearman's correlation coefficients for hepatic fat fraction (HFF) and related parameters.

\begin{tabular}{|c|c|c|}
\hline & $r$ & $P$ value \\
\hline $\operatorname{BMI}\left(\mathrm{kg} / \mathrm{m}^{2}\right)$ & 0.441 & $<0.0001$ \\
\hline Waist circumference $(\mathrm{cm})$ & 0.374 & $<0.0001$ \\
\hline WHR & 0.275 & 0.0005 \\
\hline Systolic BP (mmHg) & 0.191 & 0.0023 \\
\hline Diastolic BP (mmHg) & 0.05 & 0.3852 \\
\hline Triglycerides $(\mathrm{g} / \mathrm{L})$ & 0.219 & 0.0058 \\
\hline HDL cholesterol (g/L) & -0.062 & 0.4434 \\
\hline LDL cholesterol (g/L) & 0.021 & 0.8035 \\
\hline Glycaemia (g/L) & 0.311 & $<0.0001$ \\
\hline $\mathrm{HbA}_{1 \mathrm{c}}(\%)$ & 0.263 & 0.0009 \\
\hline HOMA-IR & 0.441 & $<0.0001$ \\
\hline VAT area $\left(\mathrm{cm}^{2}\right)$ & 0.395 & $<0.0001$ \\
\hline SAT area $\left(\mathrm{cm}^{2}\right)$ & 0.165 & 0.0458 \\
\hline Leptin $(\mu \mathrm{g} / \mathrm{L})$ & 0.281 & 0.0006 \\
\hline Adiponectin (mg/L) & -0.169 & 0.0042 \\
\hline Microalbuminuria (mg/L) & 0.124 & 0.1297 \\
\hline C-reactive protein $(\mathrm{mg} / \mathrm{L})$ & 0.244 & 0.0029 \\
\hline GGT (IU/L) & 0.201 & 0.0125 \\
\hline ALT (IU/L) & 0.419 & $<0.0001$ \\
\hline Ferritin $(\mu \mathrm{g} / \mathrm{L})$ & 0.203 & 0.0014 \\
\hline Carotid IMT (mm) & 0.139 & 0.0937 \\
\hline Carotid PWV (m/s) & 0.289 & 0.0005 \\
\hline Aortic PWV (m/s) & 0.401 & 0.0003 \\
\hline
\end{tabular}

BMI: body mass index; WHR: waist-to-hip ratio; BP: blood pressure; HDL/LDL: high-density/low-density lipoprotein; $\mathrm{HbA}_{1 \mathrm{c}}$ : glycosylated haemoglobin; HOMA-IR: homoeostasis model assessment for insulin resistance; VAT: visceral adipose tissue; SAT: subcutaneous adipose tissue; GGT: gamma-glutamyl transferase; ALT: alanine aminotransferase; IMT: intima-media thickness; PWV: pulse wave velocity.

criteria, HFF showed a median of $4.4 \%$ and a mean of $6.7 \%$, whereas the medians with two, three and four criteria were $5.12 \%, 7.7 \%$ and $17.9 \%$, respectively. Patients with all five MetS criteria had a mean HFF of $19.2 \%$. Among non-diabetic subjects, the relationship between MetS criteria and HFF was the same

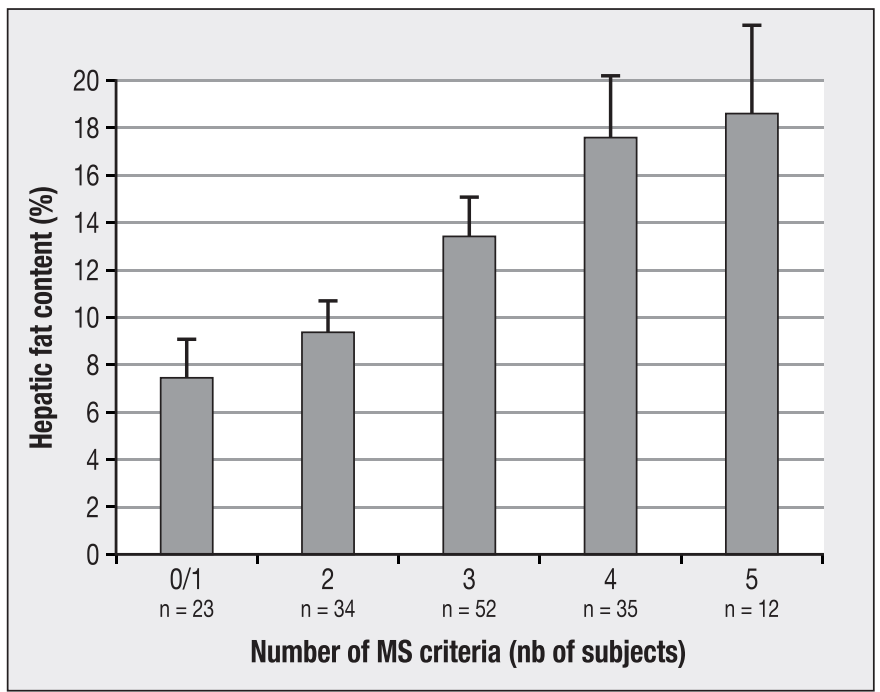

Fig. 1. Unadjusted mean levels of hepatic fat content according to the number of fulfilled criteria for the metabolic syndrome. as that found for the whole population, indicating that diabetic status had no influence on this association (results not shown).

The Youden index was used to identify an HFF cutoff value for having at least three or more MetS criteria. According to the index, the optimal HFF cutoff value to identify subjects with the MetS was $5.2 \%$. Using this value, the diagnostic accuracy, Se, Sp, PPV and NPV were 69.2\%, 76.8\%, 56.1\%, 75.2\% and $58.2 \%$, respectively. Table 4 shows the characteristics of the study population according to those with HFFs less than $5.2 \%$ and those with HFFs greater than or equal to 5.2\%. Those with a low degree of steatosis $(<5.2 \%)$ had, on average, lower systolic blood pressure $(123 \mathrm{mmHg}$ vs $130 \mathrm{mmHg} ; P=0.007)$ and lower levels of VAT $\left(141 \mathrm{~cm}^{2}\right.$ vs $\left.206 \mathrm{~cm}^{2} ; P<0.0001\right)$. They also had a lower mean insulin level in comparison to those with an HFF greater than $5.2 \%(10.9 \mathrm{mIU} / \mathrm{L} v s 16 \mathrm{mIU} / \mathrm{L})$. In addition, the group with greater than $5.2 \%$ of liver fat had a mean serum ALT level at $45 \mathrm{IU} / \mathrm{L}$ while the other group had a mean level of 30 IU/L.

\section{Discussion}

The MetS is a frequently encountered condition that associates insulin resistance, central obesity (male fat distribution), glucose and lipid profile anomalies, and hypertension, thereby increasing cardiovascular risk. Several studies have found a link between hepatic fat content as measured by magnetic resonance spectroscopy (MRS) and the MetS in various populations [15,28,29]. In the present study, a validated MFGRE T1-weighted MRI protocol was used to quantify liver fat content and showed that HFF increases in proportion to the number of metabolic traits. Moreover, a cutoff point of $5.2 \%$ for HFF was used to identify the presence of the MetS.

${ }^{1} \mathrm{H}$-MRS has been the reference standard for non-invasive steatosis quantification for several years. Using MRS, Szczepaniak et al. [16] demonstrated a threshold value of $5.5 \%$ of liver fat content, representing the 95th percentile of hepatic TG content in a representative sample of healthy American adults. Accuracy of the HFF as measured by multi-echo MRI has been compared with that of proton MRS in several previous studies [17,19]. In surgical patients, van Werven et al. [18] compared the diagnostic performance of ultrasonography, computed tomography, T1-weighted dual-echo MRI and proton MRS for the assessment of steatosis using liver resection as the gold standard. That study showed similar and high diagnostic accuracy in quantifying hepatic steatosis for both MRI and MRS vs histopathological results, while MRI was shown to be not inferior to MRS for liver fat quantification. Recently, MRI was compared with liver biopsy by Kuhn et al. [30], which resulted in an excellent correlation independent of the presence of hepatic iron or fibrosis as assessed by biopsy. Others, including the present authors, have already demonstrated the good reliability of MRI over liver biopsy for quantifying steatosis $[25,31,32]$. Thus, primarily because MRI is non-invasive and able to assess the whole liver, it represents a reliable and safe method for measuring the percentage of fat in human liver. Also, in comparison to MRS, MRI using multi-echo sequences is easily performed without the 
Table 3

Multivariate regression models evaluating the association between hepatic fat fraction and the relevant metabolic and vascular components.

\begin{tabular}{|c|c|c|c|c|}
\hline & Model 1 & Model 2 & Model 3 & Model 4 \\
\hline & $\begin{array}{l}\beta \pm \mathrm{SE} \\
P \text { value }\end{array}$ & $\begin{array}{l}\beta \pm \mathrm{SE} \\
P \text { value }\end{array}$ & $\begin{array}{l}\beta \pm \mathrm{SE} \\
P \text { value }\end{array}$ & $\begin{array}{l}\beta \pm \mathrm{SE} \\
P \text { value }\end{array}$ \\
\hline Systolic BP (mmHg) & $\begin{array}{l}0.13 \pm 0.07 \\
P=0.05\end{array}$ & $\begin{array}{l}0.11 \pm 0.07 \\
P=0.12\end{array}$ & $\begin{array}{l}0.10 \pm 0.07 \\
P=0.14\end{array}$ & $\begin{array}{l}0.07 \pm 0.07 \\
P=0.33\end{array}$ \\
\hline Log-triglycerides (g/L) & $\begin{array}{l}1.00 \pm 1.93 \\
P=0.60\end{array}$ & $\begin{array}{l}0.75 \pm 1.96 \\
P=0.70\end{array}$ & $\begin{array}{l}-0.03 \pm 1.96 \\
P=0.99\end{array}$ & $\begin{array}{l}-1.62 \pm 2.00 \\
P=0.42\end{array}$ \\
\hline $\mathrm{HbA}_{1 \mathrm{c}}(\%)$ & $\begin{array}{l}3.95 \pm 1.64 \\
P=0.0175\end{array}$ & $\begin{array}{l}4.45 \pm 1.66 \\
P=0.0083\end{array}$ & $\begin{array}{l}4.00 \pm 1.65 \\
P=0.0170\end{array}$ & $\begin{array}{l}3.49 \pm 1.63 \\
P=0.034\end{array}$ \\
\hline Glucose (g/L) & $\begin{array}{l}15.87 \pm 4.99 \\
P=0.0018\end{array}$ & $\begin{array}{l}16.54 \pm 4.98 \\
P=0.0011\end{array}$ & $\begin{array}{l}14.99 \pm 4.99 \\
P=0.0032\end{array}$ & $\begin{array}{l}13.64 \pm 5.12 \\
P=0.008\end{array}$ \\
\hline Log-insulin (mU/L) & $\begin{array}{l}6.72 \pm 1.83 \\
P=0.0004\end{array}$ & $\begin{array}{l}6.36 \pm 1.76 \\
P=0.0004\end{array}$ & $\begin{array}{l}5.88 \pm 1.88 \\
P=0.0022\end{array}$ & - \\
\hline Log-HOMA-IR & $\begin{array}{l}6.91 \pm 1.62 \\
P<0.0001\end{array}$ & $\begin{array}{l}6.49 \pm 1.54 \\
P<0.0001\end{array}$ & $\begin{array}{l}6.22 \pm 1.66 \\
P=0.0003\end{array}$ & - \\
\hline Adiponectin (mg/L) & $\begin{array}{l}-0.68 \pm 0.32 \\
P=0.0368\end{array}$ & $\begin{array}{l}-0.59 \pm 0.33 \\
P=0.074\end{array}$ & $\begin{array}{l}-0.60 \pm 0.32 \\
P=0.069\end{array}$ & $\begin{array}{l}-0.27 \pm 0.34 \\
P=0.42\end{array}$ \\
\hline C-reactive protein $(\mathrm{mg} / \mathrm{L})$ & $\begin{array}{l}1.02 \pm 0.43 \\
P=0.0197\end{array}$ & $\begin{array}{l}1.08 \pm 0.43 \\
P=0.0130\end{array}$ & $\begin{array}{l}0.94 \pm 0.42 \\
P=0.0288\end{array}$ & $\begin{array}{l}0.70 \pm 0.43 \\
P=0.11\end{array}$ \\
\hline Carotid PWV (m/s) & $\begin{array}{l}2.31 \pm 1.01 \\
P=0.0235\end{array}$ & $\begin{array}{l}2.03 \pm 1.04 \\
P=0.043\end{array}$ & $\begin{array}{l}1.83 \pm 1.03 \\
P=0.081\end{array}$ & $\begin{array}{l}1.42 \pm 1.04 \\
P=0.18\end{array}$ \\
\hline Aortic PWV (m/s) & $\begin{array}{l}0.41 \pm 0.61 \\
P=0.51\end{array}$ & $\begin{array}{l}0.84 \pm 0.67 \\
P=0.21\end{array}$ & $\begin{array}{l}0.45 \pm 0.64 \\
P=0.48\end{array}$ & $\begin{array}{l}1.05 \pm 0.62 \\
P=0.10\end{array}$ \\
\hline
\end{tabular}

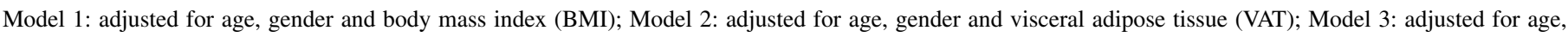

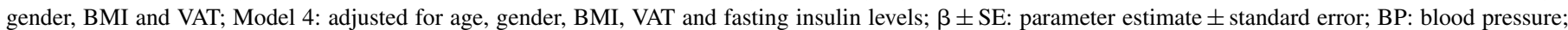
HOMA-IR: homoeostasis model assessment for insulin resistance; PWV: pulse wave velocity.

need for specialized equipment, making it widely available for clinical research on liver steatosis and its associated pathological conditions.

In our present study using MRI for liver fat quantification, it was shown that T2D patients display the same degree of steatosis as MetS+ subjects (HFFs $16.8 \%$ and $15 \%$, respectively). Hepatic glucose production is an energy-consumption process that is increased in steatosis and closely related to insulin resistance [7,8,33-35]. Thus, our study demonstrates that HFF correlates with fasting glycaemia, glycosylated haemoglobin $\left(\mathrm{HbA}_{1 \mathrm{c}}\right)$ and insulin resistance (HOMA-IR) independent of the amount of VAT and level of insulin. This argues for a direct role of liver fat content in the widespread impaired glucose tolerance seen in adults independently of VAT [5,34]. Despite glycaemia, HFF correlates with TG and systolic blood pressure, although these relationships disappear after adjusting for BMI and visceral fat mass, indicating that these two components of the MetS are more closely related to adipose fat mass than steatosis per se. As expected, ALT, ferritin and CRP were related to HFF, although the relationship with ferritin was weaker than with ALT. Some authors have recently reported that serum ferritin may be more predictive of fibrosis than simple steatosis [36].

Regarding vascular functions, some authors have described an association between carotid IMT and liver histology in NAFLD patients [37]. Other authors, including the present ones, could find no relationship between carotid wall thickness and
HFF as quantified by MRS [38,39]. Another vascular test that is closely related to the MetS is the echocardiographic PWV test, which reflects arterial stiffness [40]. Our study described for the first time a linear relationship between HFF and arterial stiffness at the level of the aorta and carotid arteries. Moreover, the HFF-carotid stiffness association was independent of BMI and visceral fat, whereas the HFF-aortic stiffness association appears to be more dependent on central obesity.

The recognition that NAFLD is an independent risk factor for CVD is a major public-health concern, but one that has yet to be fully demonstrated mainly because of the absence of reliable liver quantification in previous cohorts. While awaiting a longitudinal prospective study, Hoenig et al. [28] recently reported on a cross-sectional study of a small group of adults who all presented with high cardiovascular risk levels and steatosis as measured by spectrometry. They also showed a relationship between HFF and MetS components, but did not adjust their results for other confounding factors because of their small sample size.

In the present study, our aim was to describe for the first time in a larger cohort the relationship between HFF as measured by MRI and the metabolic components of MetS in a wide range of adults who exhibited zero to five MetS components. Our findings have revealed that the degree of steatosis increases progressively with the number of MetS components present. The optimal MRI-based HFF that best predicted the presence of at 
Table 4

Comparison of characteristics according to hepatic fat fraction (HFF) status.

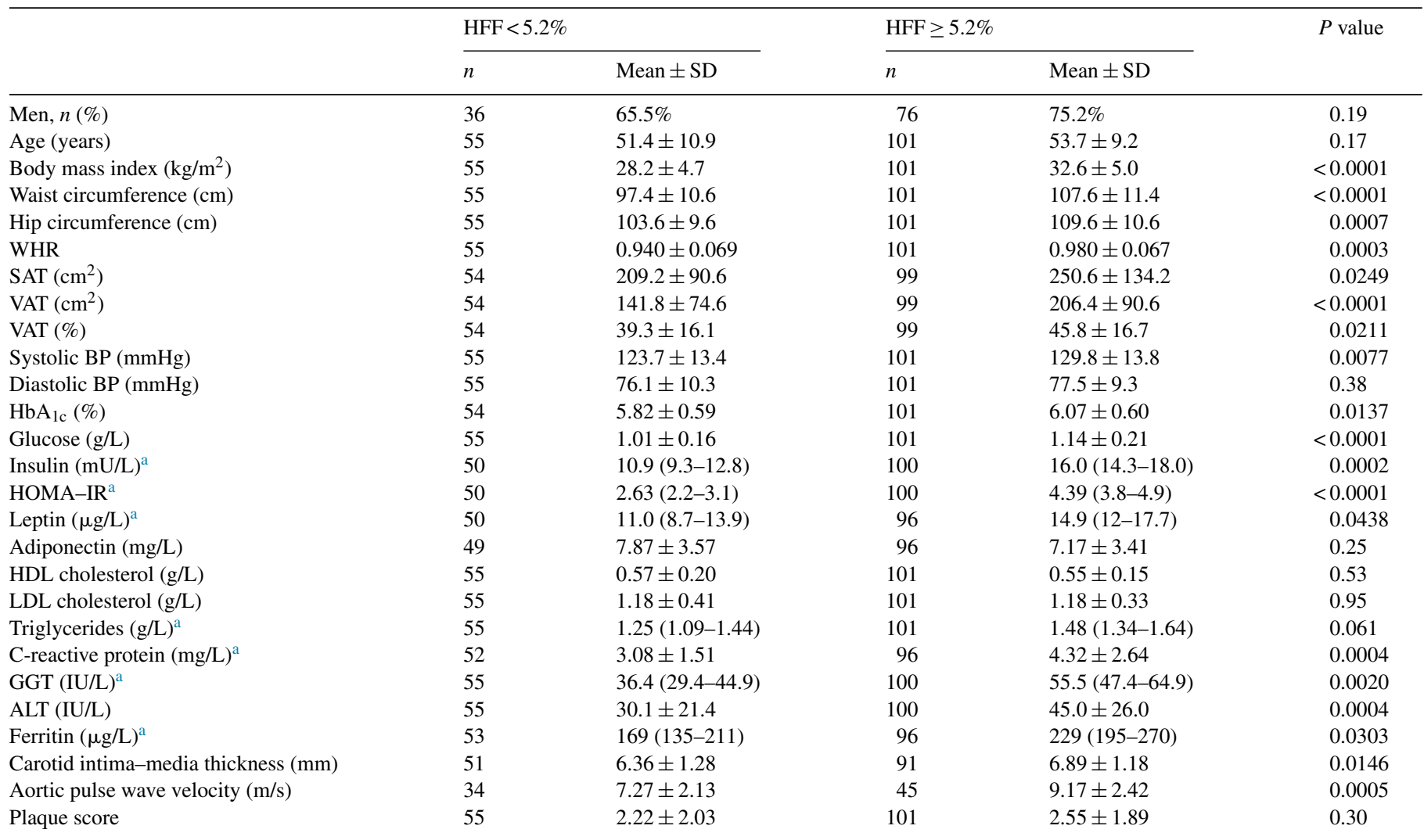

WHR: waist-to-hip ratio; SAT/VAT: subcutaneous/visceral adipose tissue; BP: blood pressure; HOMA-IR: homoeostasis model assessment of insulin resistance; HDL/LDL: high-density/low-density lipoprotein; GGT: gamma-glutamyl transferase; ALT: alanine aminotransferase.

a Skewed distribution of values: statistical tests were carried out on logarithmically transformed values; reported values are geometric means (95\% confidence intervals); for categorical variables, data are frequencies (\%) and characteristics were compared between the two groups using chi-square tests; for continuous variables, data are means \pm SD unless otherwise specified; comparisons between the two patient groups were by unpaired Student's $t$ test.

least three MetS components was $5.2 \%$, using the Youden index (which represents the best ratio of Se to Sp). Indeed, values of HFF between 5\% and 10\% displayed a Youden index closer to the highest one. It can therefore be speculated that having an HFF of 5 to $10 \%$ confers the same risk of having the MetS and that, with an HFF greater than $10 \%$, the probability of having the MetS is very high. Nevertheless, a large-scale longitudinal study is still needed to confirm that HFF indeed increases the risk of cardiovascular morbidity.

Our present results are limited by the relatively small size of the patient subgroups as well as by the cross-sectional design. The impact of liver fat deposition on cardiometabolic outcomes needs to be confirmed by longitudinal studies including records of cardiovascular events over longer durations of follow-up [37]. Another limitation of our study is the restricted availability of MRI for basic medicine. However, it may be speculated that this imaging technology will become more and more accessible, and more affordable, in the near future and therefore better serve in a strategy of preventative medicine for dysmetabolic subjects.

In conclusion, our findings in French adults have shown that HFF is associated with several metabolic components of the MetS and also has relationships with glycaemia, insulin resistance and carotid stiffness independent of visceral adiposity. Using MRI quantification, it was calculated that a cutoff value of $5.2 \%$ of HFF can identify the risk of having the MetS.

\section{Disclosure of interest}

The authors declare that they have no conflicts of interest concerning this article.

Financial support: National Clinical Research Hospital Project [Projet hospitalier de recherche clinique national (PHRC) 2008]: "Diagnosis and quantification of hepatic steatosis by MRI" (Diagnostic et quantification de la stéatose hépatique par IRM).

\section{References}

[1] Vanni E, Bugianesi E, Kotronen A, De Minicis S, Yki-Järvinen H, SvegliatiBaroni G. From the metabolic syndrome to NAFLD or vice versa? Dig Liver Dis 2010;42:320-30.

[2] Vangipurapu J, Stančáková A, Kuulasmaa T, Paananen J, Kuusisto J, et al. A novel surrogate index for hepatic insulin resistance. Diabetologia 2011;54:540-3.

[3] Samuel VT, Petersen KF, Shulman GI. Lipid-induced insulin resistance: unravelling the mechanism. Lancet 2010;375:2267-77. 
[4] Després JP, Lemieux I. Abdominal obesity and metabolic syndrome. Nature 2006;444:881-7.

[5] Fabbrini E, Magkos F, Mohammed BS, Pietka T, Abumrad NA, Patterson $\mathrm{BW}$, et al. Intrahepatic fat, not visceral fat, is linked with metabolic complications of obesity. Proc Natl Acad Sci U S A 2009;106: 15430-5.

[6] Marchesini G, Bugianesi E, Forlani G, Cerrelli F, Lenzi M, Manini R, et al. Nonalcoholic fatty liver, steatohepatitis, and the metabolic syndrome. Hepatology 2003;37:917-23.

[7] Roden M. Mechanisms of Disease: hepatic steatosis in type 2 diabetes-pathogenesis and clinical relevance. Nat Clin Pract Endocrinol Metab 2006;2:335-48.

[8] Nakamura S, Takamura T, Matsuzawa-Nagata N, Takayama H, Misu H, Noda H, et al. Palmitate induces insulin resistance in H4IIEC3 hepatocytes through reactive oxygen species produced by mitochondria. J Biol Chem 2009;284:14809-18.

[9] Angulo P. Nonalcoholic fatty liver disease. N Engl J Med 2002;346:1221-31.

[10] Gastaldelli A, Kozakova M, Højlund K, Flyvbjerg A, Favuzzi A, Mitrakou A, et al. Fatty liver is associated with insulin resistance, risk of coronary heart disease, and early atherosclerosis in a large European population. Hepatology 2009;49:1537-44.

[11] Ekstedt M, Franzén LE, Mathiesen UL, Thorelius L, Holmqvist M, Bodemar G, et al. Long-term follow-up of patients with NAFLD and elevated liver enzymes. Hepatology 2006;44:865-73.

[12] Bonnet F, Ducluzeau PH, Gastaldelli A, Laville M, Anderwald CH, Konrad $\mathrm{T}$, et al. Liver enzymes are associated with hepatic insulin resistance, insulin secretion, and glucagon concentration in healthy men and women. Diabetes 2011;60:1660-7.

[13] Boursier J, Chaigneau J, Roullier V, Lainé F, Sandrini J, Michalak S, et al. Steatosis degree, measured by morphometry, is linked to other liver lesions and metabolic syndrome components in patients with NAFLD. Eur J Gastroenterol Hepatol 2011;23:974-81.

[14] Choi S-Y, Kim D, Kim HJ, Kang JH, Chung SJ, Park MJ, et al. The relation between non-alcoholic fatty liver disease and the risk of coronary heart disease in Koreans. Am J Gastroenterol 2009;104:1953-60.

[15] Mehta SR, Thomas EL, Bell JD, Johnston DG, Taylor-Robinson SD. Noninvasive means of measuring hepatic fat content. World J Gastroenterol 2008; 14:3476-83.

[16] Szczepaniak LS, Nurenberg P, Leonard D, Browning JD, Reingold JS, Grundy S, et al. Magnetic resonance spectroscopy to measure hepatic triglyceride content: prevalence of hepatic steatosis in the general population. Am J Physiol Endocrinol Metab 2005;288:E462-8.

[17] Guiu B, Petit JM, Loffroy R, Ben Salem D, Aho S, Masson D, et al. Quantification of liver fat content: comparison of triple-echo chemical shift gradient-echo imaging and in vivo proton MR spectroscopy. Radiology 2009;250:95-102.

[18] van Werven JR, Marsman HA, Nederveen AJ, Smits NJ, ten Kate FJ, van Gulik TM, et al. Assessment of hepatic steatosis in patients undergoing liver resection: comparison of US, CT, T1-weighted dual-echo MR imaging, and point-resolved 1H MR spectroscopy. Radiology 2010;256: $159-68$.

[19] Meisamy S, Hines CD, Hamilton G, Sirlin CB, McKenzie CA, Yu H, et al. Quantification of hepatic steatosis with T1-independent, T2-corrected MR imaging with spectral modelling of fat: blinded comparison with MR spectroscopy. Radiology 2011;258:767-75.

[20] Ishizaka K, Oyama N, Mito S, Sugimori H, Nakanishi M, Okuaki T, et al. Comparison of 1H MR spectroscopy, 3-point DIXON, and multi-echo gradient echo for measuring hepatic fat fraction. Magn Reson Med Sci 2011;10:41-8.

[21] Raptis DA, Fischer MA, Graf R, Nanz D, Weber A, Moritz W, et al. MRI: the new reference standard in quantifying hepatic steatosis? Gut 2012;61:117-27.
[22] Alberti KGMM, Zimmet P, Shaw J. The metabolic syndrome - a new worldwide definition. Lancet 2005;366:1059-62.

[23] Illouz F, Roulier V, Rod A, Gallois Y, Pellé CP, Aubé C, et al. Distribution of adipose tissue: quantification and relationship with hepatic steatosis and vascular profiles of type 2 diabetic patients with metabolic syndrome. Diabetes Metab 2008;34:68-74.

[24] Ducluzeau P-H, Manchec-Poilblanc P, Roullier V, Cesbron E, Lebigot J, Bertrais S, et al. Distribution of abdominal adipose tissue as a predictor of hepatic steatosis assessed by MRI. Clin Radiol 2010;65:695-700.

[25] Cesbron-Métivier E, Roullier V, Boursier J, Cavaro-Ménard C, Lebigot J, Michalak S, et al. Noninvasive liver steatosis quantification using MRI techniques combined with blood markers. Eur J Gastroenterol Hepatol 2010;22:973-82.

[26] Boutouyrie P, Briet M, Collin C, Laurent S, Tan A, Azizi M, et al. Assessment of pulse wavevelocity. Artery Res 2009;3:3-8.

[27] Harada A, Okada T, Niki K, Chang D, Sugawara M. On-line noninvasive one-point measurements of pulse wave velocity. Heart Vessels 2002;17:61-8.

[28] Hoenig MR, Cowin G, Buckley R, McHenery C, Coulthard A. Liver fat percent is associated with metabolic risk factors and the metabolic syndrome in a high-risk vascular cohort. Nutr Metab (Lond) 2010;7:50-5.

[29] Hsiao P-J, Kuo K-K, Shin S-J, Yang YH, Lin WY, Yang JF, et al. Significant correlations between severe fatty liver and risk factors for metabolic syndrome. J Gastroenterol Hepatol 2007;22:2118-23.

[30] Kühn JP, Evert M, Friedrich N, Kannengiesser S, Mayerle J, Thiel R, et al. Noninvasive quantification of hepatic fat content using three-echo dixon magnetic resonance imaging with correction for $\mathrm{T} 2 *$ relaxation effects. Invest Radiol 2011;46:783-9.

[31] Hatta T, Fujinaga Y, Kadoya M, Ueda H, Murayama H, Kurozumi $\mathrm{M}$, et al. Accurate and simple method for quantification of hepatic fat content using magnetic resonance imaging: a prospective study in biopsy-proven nonalcoholic fatty liver disease. J Gastroenterol 2010;45: 1263-71.

[32] Mennesson N, Dumortier J, Hervieu V, Milot L, Guillaud O, Scoazec JY, et al. Liver steatosis quantification using magnetic resonance imaging: a prospective comparative study with liver biopsy. J Comput Assist Tomogr 2009;33:672-7.

[33] van der Poorten D, Milner K-L, Hui J, Hodge A, Trenell MI, Kench JG, et al. Visceral fat: a key mediator of steatohepatitis in metabolic liver disease. Hepatology 2008;48:449-57.

[34] Bae JC, Rhee EJ, Lee WY, Park SE, Park CY, Oh KW, et al. Combined effect of nonalcoholic fatty liver disease and impaired fasting glucose on the development of type 2 diabetes: a 4-year retrospective longitudinal study. Diabetes Care 2011;34:727-9.

[35] Wasada T, Kasahara T, Wada J, Jimba S, Fujimaki R, Nakagami T, et al. Hepatic steatosis rather than visceral adiposity is more closely associated with insulin resistance in the early stage of obesity. Metab Clin Exp 2008;57:980-5.

[36] Kowdley KV, Belt P, Wilson LA, Yeh MM, Neuschwander-Tetri BA, Chalasani N, et al. Serum ferritin is an independent predictor of histologic severity and advanced fibrosis in patients with nonalcoholic fatty liver disease. Hepatology 2012;55:77-85.

[37] Targher G, Day CP, Bonora E. Risk of cardiovascular disease in patients with nonalcoholic fatty liver disease. N Engl J Med 2010;363:1341-50.

[38] Petit JM, Guiu B, Terriat B, Loffroy R, Robin I, Petit V, et al. Nonalcoholic fatty liver is not associated with carotid intima-media thickness in type 2 diabtes patients. J Clin Endocrinol Metab 2009;94:4103-6.

[39] Salvi P, Ruffini R, Agnoletti D, Magnani E, Pagliarani G, Comandini G, et al. Increased arterial stiffness in nonalcoholic fatty liver disease: the Cardio-GOOSE study. J Hypertens 2010;28:1699-707.

[40] Nakanishi N, Suzuki K, Tatara K. Clustered features of the metabolic syndrome and the risk for increased aortic pulse wave velocity in middle-aged Japanese men. Angiology 2003;54:551-9. 